\title{
Inalienable Rights of Property: A Study of Contract Obligations and Other Vested Rights
}

\section{Individual Rights of Specific Individuals Under Transactions With Public Authorities.}

Whether public authorities may incur indefeasible contract obligations in favor of individuals.-A state, or public authority thereof that is duly empowered, may enter into a valid and binding contract with a private individual, the obligation of which can no more be impaired by subsequent legislation than can the obligation of a contract between two or more private individuals. ${ }^{1}$ In case of the alteration or repeal of the act by acceptance of which the contract arose, the contract continues to possess the same operative and binding force as before." "The legislature cannot, by merely changing the name of a municipal corporation, or by abridging or enlarging its territory, so destroy its identity as to impair the rights of its creditors to the enforcement of their obligations against the original corporation." 3 An attempt by the legislature to extinguish the debts of a city by disincorporating the city and causing

1 People v. Brooks (1860), 16 Cal. 11, 47, 50; Hutton v. Frisbie (1869), 37 Cal. 475, 511; Rose v. Estudillo (1870), 39 Cal. 270, 274; Floyd v. Blanding (1879), $54 \mathrm{Cal}$. 41, 45, 4 Pac. Coast L. J. 424; San Francisco Gas Light Co. v. Dunn (1882), 62 Cal. 580, 585, 8 Pac. Coast L. J. 1083. Contra, Myers v. English (1858), 9 Cal. 342, 349, 351.

2 People v. Brooks (1860), 16 Cal. 11, 33, 50; "If the legislature could destroy a contract entered into by the state by the repeal of the law which authorized it, no contract could ever be made binding upon the state. The performance of the stipulation of any contract on her part, and the obligations to such performance, would depend purely upon the will of the legislature. Such a proposition cannot be maintained." Babcock v. Middleton (1862), $20 \mathrm{Cal} .643,656$.

3 Bates v. Gregory (1891), 89 Cal. 387, 395, 26 Pac. 891, the court holding (pp. 395-7), that where Sacramento city was incorporated by Stats. 1851 , p. 391, with certain boundaries, and by Stats. 1858, p. 267, the city and county of Sacramento were consolidated into one government covering the whole territory of both, and by Stats. 1863 , p. 415 , the city of Sacramento was reconstituted as a distinct municipal corporation with the original boundaries, the legislature did not by such changes impair the rights of the holders of certain bonds duly issued by the original city to bring and maintain suit thereon against the city as reconstituted. 
its property which was subject to execution to escheat to the state, and thereupon incorporating a new city within the same territorial limits but without debts, would be unconstitutional and void. ${ }^{4}$ Where Reclamation District No. 70 (New 70 ) was created and its boundaries fixed by statute ${ }^{5}$ and as so constituted it embraced within its limits all the territory of Swamp Land District No.7o (Old 70) besides other territory, the absorption of Old 70 by New 70 , and, to that extent, extinguishment of the existence of Old 70 could not, even should the legislature so design, operate to impair any of the rights of the creditors of Old 70 in existence at the time New 70 was created, nor to so completely destroy Old 70 as to render the just claims of its creditors unenforceable against it. ${ }^{6}$ Where the State Board of Harbor Commissioners, in consideration of wharfage paid it, received upon one of its public wharves at San Francisco a consignment of coal, and by reason of want of ordinary care in the upkeep of the wharf, it gave way under the coal, and the coal was lost in the waters of the bay, the state was bound by such contract to the same extent that an individual engaged in the same business would have been by a similar contract, and was liable to that extent for its breach of contract in failing to exercise ordinary care for the safety of the coal, although the usual remedies for breach of contract were not available against it. ${ }^{7}$

What amounts to contract between individual and public authority.-The existence of a contract between an individual and a public authority must be established clearly and not by vague conjecture or plausible presumption. ${ }^{8}$ Yet that there may be a valid and binding contract between the state and a private individual, it is not necessary that there be a consideration moving from the individual to the state; it is sufficient that, on the faith of the contract, the individual has invested his money or employed his time and labor in furtherance of the enterprise which is the subjectmatter of the contract. ${ }^{9}$

Thus where a statute of $185^{10}$ required the State Board of Prison Commissioners to lease for five years the state prison

4 Smith v. Morse (1852), 2 Cal. 524, 555.

5 Cal. Stats. 1905 , p. 717.

113 Pac. 170.

${ }^{6}$ Reclamation District No. 70 v. Birks (1911), 159 Cal. 233, 238,

7 Chapman v. California (1894), 104 Cal. 690, 694, 38 Pac. 457, 43

Am. St. Rep. 158.

8 Floyd v. Blanding (1879), 54 Cal. 41, 47, 4 Pac. Coast L. J. 424.

9 Floyd v. Blanding (1879), 54 Cal. 41, 45, 4 Pac. Coast L. J. 424.

$10 \mathrm{Cal}$. Stats. 1856 , p. 48. 
grounds and property with the labor of the convicts, the lease thereof to require the lessee to take full control, custody and care of all convicts and erect at his own expense such buildings as would conduce to the safekeeping and working of the convicts, and to entitle the lessee to the labor of the convicts and to payment by the state of a monthly sum fixed by the lease, not exceeding fifteen thousand dollars appropriated from the state treasury per month for each month of the lease the amount of the payment specified in the lease, and required the state controller to "draw his warrants on the treasurer of the state for said sum" each month, and the treasurer "to pay the said warrants on application of said lessee in writing on the last day of each month," a five-year lease, made pursuant to said act, and providing for a monthly payment of ten thousand dollars to the lessee, constituted a contract, valid against and binding upon the state. ${ }^{11}$

Subsequently, when the validity of this contract was again unsuccessfully questioned, the Supreme Court, as an additional reason for affirming its validity, declared $:^{12}$

"We do not admit that an affirmation of a contract entered into by the agents of the state, upon a subject within the constitutional control of the legislature, can only be made by direct legislative action in terms designating such contract. On the contrary, such affirmation may be justly inferred from legislation indirectly referring to the contract, or proceeding upon its assumed validity.

"Thus, in the act of April 7th, I856, appropriating moneys to defray the expenses of the [state] prison up to March 28th, passed after a copy of the contract with Estill (whereby he took the five-year lease) had been transmitted to the senate, the legislature recognized the existence and in effect the validity of the contract in the provision that no person should receive any pay for supplies furnished under any contract with the directors of the prison until he surrendered such contract and released the state from all liability for such supplies furnished after the leasing of said prison by the Board of Commissioners under an act passed at this session of the legislature. That provision was manifestly adopted upon the supposition that the responsibility for supplies furnished subsequently to the time the prison was received by the lessee, had devolved upon him, and that the contract for the leasing, imposing such responsibility, was valid and binding."

11 California v. McCauley (1860), 15 Cal. 429, 457.

12 People v. Brooks (1860), 16 Cal. 11, 26. 
Hence the provision of the statute of $1859^{13}$ repealing the statute of $1856^{14}$ above referred to, did not and could not abrogate or in any wise impair such lease or the obligation of the state to make the payments thereunder. ${ }^{15}$

Where a statute ${ }^{16}$ authorized the funding of the floating debt of San Francisco by exchange for twenty-year ten per cent bonds, known as "city stock," and provided for the collection of an annual tax for the payment of interest on such stock and its retirement at or before maturity, the act must be regarded as authorizing a contract between the city and the holders of such floating indebtedness, and upon exchange by any holder thereof of his old demand for city stock a new and binding contract between the city and such holder arose. ${ }^{17}$ Similarly, where the legislature authorized ${ }^{18}$ the funding of the floating debt of Sacramento County by exchange for ten per cent bonds, payable not later than ten years after date, and (section 5) required the Court of Sessions to assess annually, in addition to other taxes, a property tax of one-fourth of one per cent to constitute a sinking fund for the redemption of the bonds, the fifth section of the act constituted a contract between the county and those who exchanged their old demands for the bonds. ${ }^{19}$ And where a statute ${ }^{20}$ consolidating the city and county of Sacramento and providing government therefor, made provision for the levy within the old city limits of a property tax of one dollar on each hundred dollars for city purposes, for the application of certain other revenue to city purposes, for funding the outstanding indebtedness of the city by exchange for six per cent bonds, and for the application of fifty-five per cent of the revenue for city purposes to interest on the bonds and to a sinking fund for their retirement, and such bonds were issued and were accepted by the creditors of the city in payment of their claims, a contract within the constitutional protection between the new municipality and the bondholders resulted. ${ }^{21}$

13 Cal. Stats. 1859 , p. $374, \S 13$.

14 Cal. Stats. 1856 , p. 48 , c. 39.

15 People v. Brooks (1860), 16 Cal. 11, 33, 50.

${ }^{16}$ Cal. Stats. 1851 , p. 387.

17 People v. Woods (1857), 7 Cal. 579, 584; People v. Bond (1858), 10 Cal. 563, 570; Board of Education v. Fowler (1861), 19 Cal. 11, 23; Babcock v. Middleton (1862), 20 Cal. 643, 656.

18 Cal. Stats. 1854, p. 201.

19 English v. Board of Supervisors (1861), 19 Cal. 172.

${ }^{20}$ Cal. Stats. 1858 , p. 267.

21 Meyer v. Brown (1884), 65 Cal. 583, 589, 26 Pac. 281; Bates v. Porter (1887), 74 Cal. 224, 237, 238, 15 Pac. 732. 
On the other hand, where a statute ${ }^{22}$ fixed the San Francisco water front line, granted the use and occupation for ninety-nine years of certain water lots to the city, or where the city had already granted the same, to its grantees, and provided that "the boundary line described .... shall be and remain a permanent water front of said city," and that "nothing in this act shall be construed as a surrender by the state of its rights to regulate the construction of wharves and other improvements," and such a prior grantee of a lot that was separated only by an intervening street from the waterline defined in the act, reclaimed his lot and constructed thereon a warehouse, there was no contract between him and the state; and the State Board of Harbor Commissioners were not debarred from afterwards re-establishing the water front further off shore. ${ }^{23}$

Where a statute ${ }^{24}$ relating to the incorporation of companies to supply municipalities with water, gave each such company the right to use the public streets and places for its pipes and to condemn private property, on condition that it furnish pure fresh water to the inhabitants at reasonable rates and without discrimination, and to the municipality free of charge "in case of fire or other great necessity," and provided that water rates should be determined annually by a board of commissioners selected, two by the municipal authorities and two by the water company, and in case the four could not agree, the four to choose a fifth member of the board, or if the four could not agree upon the fifth, then the sheriff to appoint the fifth, and the Spring Valley Water Works incorporated under said act, and supplied water to San Francisco and its inhabitants thereunder, a contract was not thereby created which prevented the application to the water company of the provision of Article XIV, section one, of the constitution of 1879 , making the board of supervisors of the municipality, in lieu of said board of commissioners, the rate-fixing tribunal. ${ }^{25}$

Rights acquired in the national domain by proceedings to purchase.-The Act of Congress of $184 \mathrm{I}^{28}$ authorized entry with a Register of a United States district land office of not to exceed a quarter section of United States public lands, by legal subdivisions, when the following conditions concurred:

22 Cal. Stats. 1851, p. 307.

23 Floyd v. Blanding (1879), 54 Cal. 41, 4 Pac. Coast L. J. 424.

24 Cal. Stats. 1858, p. 218.

25 Supra, n. 36.

$=5$ Stats. at L. 453. 
(I) The land must have been surveyed prior to entry, and must not be of certain excepted kinds and classes.

(2) The pre-emptioner must be over twenty-one years of age, a United States citizen, or must have filed his declaration of intention to become one.

(3) The pre-emptioner must not own more than three hundred and twenty acres of land in the United States, and must not have quit or abandoned a residence on his own land, and must not be entitled to any other pre-emptive right.

(4) The pre-emptioner must have made settlement in person on the land he proposes to pre-empt since June I, I840, must erect a dwelling and actually reside thereon, and must undertake to improve the same.

Section II of the act provided that as between persons equally entitled under the act, the first settler on a given legal subdivision, complying with the act, is entitled to pre-empt. The Act of Congress of $1853^{27}$ as modified by Act of Congress of $1854,{ }^{28}$ made public lands in California, subject to certain provisos, subject to the foregoing act, "with all the exceptions, conditions and limitations thereof." The Act of Congress of $1862^{29}$ extended the privilege of settlement upon unsurveyed lands to California, but required the pre-emptioner to file his declaratory statement within three months after the receipt at the district land office of the approved plat of the township embracing such pre-emption settlement. Under these acts, mere occupation and improvement of United States lands, with intention to pre-empt, did not confer such a vested interest in the land occupied as to impair in any respect the power of Congress to grant it to another, or otherwise dispose of it. The power of Congress ceases only when all the preliminary acts prescribed by the pre-emption laws for the acquisition of title, including payment or offer of payment of the purchase price, have been performed by the settler. Only then, for the first time, the settler acquires a vested interest in the land occupied by him, of which he cannot subsequently be deprived. ${ }^{30}$

\section{By proceedings to exchange.-The Act of Congress of 1897}

2710 Stats. at I. 244.

2810 Stats. at L. 268.

2912 Stats. at L. 409.

30 Hutton v. Frisbie (1869), 37 Cal. 475, per Sawyer, C. J., Rhodes and Sanderson, JJ., in leading opinion (p. 491), Crockett and Sprague, JJ., dissenting (p. 504), on the ground that occupation and improvement, without payment, created a vested right; The Yosemite Valley Case (Hutchings v. Low) (1873), 15 Wall. 77, 21 L. Ed. 82, affirming Low v. Hutchings (1871), 41 Cal. 634, 638. 
provided" "that in cases in which a tract covered by an unperfected bona fide claim or by a patent is included within the limits of a public forest reservation .... the owner thereof may, if he desires to do so, relinquish the tract to the government, and may select in lieu thereof a tract of vacant land open to settlement not exceeding in area the tract covered by his ... . patent." In the rules and regulations governing Forest Reserves, adopted by the Land Department ${ }^{32}$ it was provided that in his application for an exchange of lands under the foregoing act the applicant must "describe the tract selected and the tract covered by the unperfected entry," and that where final certificate or patent has issued the applicant must execute and record a quitclaim deed to the United States of his land within the reserve, and furnish an abstract showing a chain of title from the United States and back again to the United States. Under these provisions, where in June, I899, a patentee of land within a forest reserve, without selecting a tract in lieu thereof, recorded a quitclaim deed thereof to the United States and filed the same with a sufficient abstract in the United States land office at Visalia, and from that office the papers were forwarded to the commissioner of the general land office, who held them without action until January 3, 1995, and then returned them to the patentee, the patentee never had any contract with the United States, and never obtained a vested right to make a selection of lieu lands under the act of 1897 ; and the repeal by $\mathrm{Act}^{33}$ of Congress of 1905 of the provision of the act of 1897 authorizing the exchange, put an end to his right to make the exchange, and his attempt later to select lieu lands was unavailing. ${ }^{34}$

Rights acquired in state lands by proceedings to purchase.-One qualified under the law existing at the time of his application to purchase state land, upon complying with all the requirements of the law and paying for the land and receiving his certificate of purchase, becomes entitled to a patent, and no subsequent constitutional or statutory enactment will be effectual to deprive him of the right so acquired. ${ }^{35}$ "Where a valid contract of sale has been entered into pursuant to law between the state and a purchaser so

3130 Stats. at L. 11.

3224 Land Dec. 589.

3333 Stats. at L. 1264.

34 Roughton v. Knight (1911), 219 U. S. 537, 55 L. Ed. 569, 31 Sup. Ct. Rep. 297, affirming (1909), 156 Cal. 123, 125, 103 Pac. 834.

35 Boggs v. Ganeard (1906), 148 Cal. 711, 716, 84 Pac. 195. 
that an equitable interest in the land is vested in the latter, the state will, of course, be prevented by force of familiar constitutional provisions from destroying the right so vested .... But where there is no contract and no vested right in the intending purchaser, the withdrawal of the land from sale by repeal of the statute authorizing or otherwise, absolutely terminates the power of the officers of the government to take the steps necessary to transfer title." ${ }^{36}$ The mere application to purchase state land, without payment of money, vests no rights in such applicant. ${ }^{37}$

The question as to when an applicant to purchase state land obtains a binding contract with the state and vested rights, has arisen in this state most often with reference to the sale of swamp and overflowed, salt marsh and tide lands. The statute of 1868 , relatimg to the management and sale of lands belonging to the state, provided $^{38}$ for the sale of state lands of the class mentioned at one dollar per acre, prescribed the contents of applications to purchase such land and the qualifications of applicants, required applications to be made to the county surveyor, directed the county surveyor, when the land applied for had not been surveyed, to make a survey thereof, and the Surveyor-General to examine such survey when made, and if found correct, approve it, required the applicant within fifty days after such approval to pay to the county treasurer twenty per cent of the purchase price and the first year's interest on the residue, and thereafter to pay such interest annually in advance and the entire residue not later than one year after passage by the legislature of an act requiring payment thereof, and provided that whenever the county treasurer reported to the Register of the State Land Office that the first payment of principal and interest had been made, the Register should issue a certificate of purchase. This act formed the basis of, and provided a scheme essentially similar to that afterwards included in, the Political Code, section 3440 of the code being similar to section 28 of the act, and sections $3443-5$ of the code to section 29 of the act, except that under the code the original application was filed with the Surveyor-General instead of the county surveyor. Under these provisions, an applicant has no contract with the state, and no vested rights, until his

36 Messenger v. Kingsbury (1910), 158 Cal. 611, 615, 112 Pac. 65.

37 Craycroft v. Superior Court (1912), 18 Cal. App. 781, 786, 124 Pac. 1042.

38 Cal. Stats. $1867-8$, p. 507, 514. 
application is approved and his first payment made. ${ }^{1}$ But upon payment of the first installment of purchase money to the proper officers of the state and its acceptance by them, the purchaser's right to the land at once vests in him, ${ }^{2}$ provided that at such time the land is open to purchase. ${ }^{3}$ The issuance of patent is not necessary to the vesting."

It follows that the provisions of Article XVII, section three, of the Constitution, restricting the sale of public land suitable for cultivation to actual settlers, may be given full force and effect as against an applicant to purchase such land who had not paid any part of the purchase price of his land at the time the Constitution took effect, without impairing any contract obligation or vested right; ${ }^{5}$ but has no application where any part of the purchase price had been paid to and accepted by the proper officers of the state at that time. ${ }^{8}$ The same is true as touching the provision of Article XV, section two, of the Constitution, reserving a right of way to navigable water, for every public use, over all tide lands

1 Eckart v. Campbell (1870), 39 Cal. 256; Klauber v. Higgins (1897), 117 Cal. 451, 459, 49 Pac. 466; Messenger v. Kingsbury (1910), 158 Cal. 611, 615, 112 Pac. 65; Polk v. Sleeper (1910), 158 Cal. 632, 634, $112 \mathrm{Pac}$ 179; People v. California Fish Company (1913), 166 Cal. 576, 138 Pac. 79. 2 McCabe v. Goodwin (1895), 106 Cal. 486, 490, 39 Pac. 941, where the early act of 1858 , Stats. 1858 , p. 198 , relating to swamp and overflowed lands was involved, and the purchasers had made all payments; People v. Banning Company (1913), 166 Cal. 635, 638, 138 Pac. 101, where the first payment of 20 per cent only was made and accepted.

3 Where certain tide lands were within two miles of the town of Wilmington as incorporated February 20, 1872, and disincorporated March 12,1887 , and of San Pedro as incorporated March 1, 1888, but in the interval between the disincorporation of Wilmington and the incorporation of San Pedro were not within two miles of any incorporated city or town, and a would-be purchaser thereof made his first payment March 7, 1882, and his last payment December 24, 1890, and received patent October 16, 1894, but made no payment between March 12, 1887, and March 1, 1888, under Art. XV, $\S 3$, of the Constitution, withdrawing tide lands within two miles of an incorporated city or town from grant or sale, the patent was void. People v. Banning Company (1914), 167 Cal. 643, 645, 140 Pac. 587.

4 McCabe v. Goodwin (1895), 106 Cal. 486, 490, 39 Pac. 941.

5 Johnson v. Squires (1880), 55 Cal. 103, 105, 5 Pac. Coast L. J. 620; Urton v. Wilson (1884), $65 \mathrm{Cal}$. 11, 2 Pac. 411; Manley v. Cunningham (1887), 72 Cal. 236, 242, 13 Pac. 622.

${ }^{6}$ Laugenour v. Shanklin (1880), 57 Cal. 70, 76, 7 Pac. Coast L. J. 140, where a person on July 1, 1852, purchased two certain land warrants from the state, each for 160 acres, for $\$ 650$ actually paid into the state treasury, and on July 13,1864, presented to and filed with the locating officer of the state for the Marysville Land District his request (in due form) to purchase certain described land from the state by the location of such land warrants thereon, and at the time of making such request surrendered to the locating agent, in payment for said land, such land warrants. 
fronting on any navigable water $;^{7}$ and of Article $X V$, section three, withholding from grant or sale all tide lands fronting on navigable waters and within two miles of any incorporated city or town of this state. ${ }^{8}$

Moreover, where the Surveyor-General refused to receive or file a certain application to purchase lands between high and low tide lines, which lands could be reclaimed without interference with navigation or fisheries, and did not approve the survey thereof, and the applicant never paid any part of the purchase price, and subsequently ${ }^{9}$ section 3443 a, withdrawing from sale lands between high and low water, was added to the Political Code, the applicant had no vested right in the lands in question, and their withdrawal from sale absolutely terminated his right to purchase. ${ }^{10}$

And where section 3499 of the Political Code ${ }^{11}$ limited the time for initiating and disposing of contests of the right to purchase school lands to five years from the date of issuance of the certificate of purchase, and made the limitation applicable to pending as well as future contests, the application of the amendment so as to quash a pending contest, brought by a contestant who had not paid any part of the purchase price of the land in question, is proper; he has no vested right to be protected. ${ }^{12}$

On the other hand, where a statute ${ }^{13}$ relating to the sale of land inuring to the state through the recession or drainage of the waters of inland lakes, provided that the selling price thereof should be

${ }^{7}$ People v. California Fish Company (1913), 166 Cal. 576, 588, 613, 138 Pac. 79, where application to purchase certain tide lands was made before the Constitution of 1879 took effect, but the first instalment of purchase money was not paid until March 5,1880, and the court held the purchase subject to Art. XII, $\$ 2$, of the Constitution.

8 People v. Banning Company (1913), 166 Cal. 635, 638, 138 Pac. 101, where the application to purchase and survey was approved and the first payment on the purchase price paid to and accepted by the proper officers February 28, 1888, and San Pedro was not incorporated until March 1, 1888, a binding contract arose before the incorporation of the city which the state was bound to complete; People v. Banning Company (1914), 167 Cal. 643, 645, 140 Pac. 587.

In Klauber v. Higgins (1897), $117 \mathrm{Cal}$ 451, 463, 49 Pac. 466, a statute similar to Art. XV, $\$ 3$, Stats. $1869-70$, p. 875, amendatory of $\$ 70$ of Stats. $1867-8$, p. 507, was passed after an application to purchase tide lands within two miles of San Diego city had been made, and before the application was approved or first payment made; and a subsequent attempt on the part of the officers of the state to complete the sale, and the patent issued in pursuance thereof, were held void.

${ }^{9}$ Cal. Stats. 1909 , p. 774.

10 Messenger v. Kingsbury (1910), 158 Cal. 611, 615, 112 Pac. 65.

11 As amended by Cal. Stats. 1911, p. 345 . 1042.

12 Craycroft v. Superior Court (1912), 18 Cal. App. 781, 786, 124 Pac.

${ }^{13}$ Cal. Stats. 1893, p. 341. 
"paid into the school fund of the county where the land lies," and that if the reclamation of land sold was necessary, all provisions of law regulating the reclamation of swamp and overflowed lands should apply, and the law so referred to provided ${ }^{14}$ that upon the completion of the reclamation works the purchase price of the land within the reclamation district should,--subject to certain deductions,-be repaid to the purchasers, the provision for such repayment constituted a contract between purchasers and the state which the state could not disregard. ${ }^{15}$

Franchise rights.-A franchise is, in the grantee thereof, a vested right of property, subject, however, in most cases, to the performance of conditions upon the part of the grantee, and so long as these are performed, cannot be divested, or transferred to another, by legislative authority, the grantee not consenting. ${ }^{16}$

Thus to the extent that a telegraph corporation, by constructing, maintaining and operating telegraph lines along and upon public streets in Los Angeles city, accepted the grant contained in section 536 of the Civil Code, which provided: "Telegraph corporations may construct lines of telegraph along and upon any public road or highway, along or across any of the waters or lands within this state, and may erect poles, posts, piers, or abutments for supporting the insulators, wires, and other necessary fixtures of their lines, in such manner and at such points as not to incommode the public use of the road or highway or interrupt the navigation of the waters;" it secured a vested right, subject only to the proper exercise of the police power. ${ }^{17}$

Where a gas company by constructing and operating in a portion of Los Angeles city gas works and a distributing system of much larger capacity than requisite to supply the territory then reached and of so great size that they could not be operated profitably without contemplated extensions into other territory, and by supplying gas light to inhabitants in territory then reached, and contracting to supply it to inhabitants not then reached, had accepted as to all streets necessary to serve the whole city the franchise offered by Article XI, section nineteen, ${ }^{18}$ of the state consti-

14 Cal. Pol. Code, \$ 3477.

15 McCord v. Slavin (1904), 143 Cal. 325, 331, 332, 76 Pac. 1104.

16 Fall v. Sutter County (1862), 21 Cal. 238, 252; California State Telegraph Co. v. Alta Telegraph Co. (1863), 22 Cal. 398, 422, 425, 429.

17 Western Union Telegraph Co. v. Hopkins (1911), 160 Cal. 106, 119, 116 Pac. 557.

18 Before the amendment of 1911 this provided: "In any city where there are no public works owned and controlled by the municipality for 
tution, the grant, resulting from the acceptance, constituted a contract, and vested in the company a property right, protected by .the Federal Constitution, which the state could not take away by the amendment of I9I I to said constitutional provision. ${ }^{19}$

Where, however, a franchise to construct and maintain a bridge and collect tolls thereon for twenty years is not by its terms exclusive, it does not divest the legislature of all power to grant a similar franchise to any other person in the same vicinity, and the grantee does not have the right to insist that no franchise of like kind the effect of which will be to impair the value and take away the profits of his own shall be granted, nor to insist that the public authorities shall not build a free bridge with similar effect. ${ }^{20}$

And where at the time a cable railroad was constructed in Los Angeles city pursuant to a franchise therefor, it was provided in section 499 of the Civil Code that, "Two lines of street-railway, operated under different managements, may be permitted to use the same street, each paying an equal portion for the construction of the track and appurtenances used by said railways jointly," the reservation of section 499 entered into the contract of the cable company, and it did not have any exclusive right to the portion of the street in which its road was constructed, and a subsequent grant of franchises for an electric road, extending for three blocks over the route of the cable road, and the entry by the electric road into joint use of the tracks of the cable road on such three blocks

supplying the same with water or artificial light, any individual or ... company .... shall .... have the privilege of using the public streets .... thereof, and of laying down pipes and conduits therein, and connections therewith, so far as may be necessary for introducing into and supplying such city and its inhabitants either with .... illuminating light, or with fresh water :... upon the condition that the municipal government shall have the right to regulate the charges thereof."

19 Russell v. Sebastian (1914), 233 U. S. 195, 58 L. Ed. 912, 34 Sup. Ct. Rep. 517, Ann. Cas. 1914C 1282, reversing Matter of Russell (1912), 163 Cal. 668, 676, 126 Pac. 875, Ann. Cas. 1914A 152, where it had been held that the acceptance extended only to streets actually occupied when the amendment of 1911, repealing the state's offer theretofore contained in Art. XI, \& 19, took effect; Oro Electric Corporation v. Railroad Commission (1915), 169 Cal. 466, 480, 147 Pac. 118.

Where on October 10,1911, when the amendment to Art. XI, \& 19, of the state constitution was approved, a corporation engaged in supplying the inhabitants of San Francisco with gas and electric light had pipes and conduits for that purpose in various public streets of the municipality, including 6th Street between Stevenson and Jessie, it on said day had a vested right to occupy such part of the street for the purpose specified in $\S 19$, and subject to the limitations therein contained. Matter of Application of Keppelmann (1914), 166 Cal. 770, 773, 138 Pac. 346.

${ }_{20}$ Fall v. Sutter County (1862), 21 Cal. 238, 252. 
was not a taking of private property for public use and did not involve an exercise of the power of eminent domain. ${ }^{21}$

\section{Rights of Individuals in Specific Property.}

Power of testamentary disposition.-The power of testamentary disposition is not an essential incident of property; and the legislature can, without depriving a husband of any vested right of property, take from him testamentary power with reference either to the community or his separate property. ${ }^{22}$

Property by succession.-The right of an heir to his inheritance depends upon positive law, and is not a natural or absolute right; and it is competent for the legislature to change the rule of inheritance, to restrict the testamentary power, and to provide that the heir or devisee shall take subject to certain burdens, such, for instance, as the payment of the decedent's debts or a family allowance. ${ }^{23}$ Statutes of descent are always subject to legislative control and may be changed or abolished at will, because the right of descent, being a mere expectancy, is not a vested right. ${ }^{24}$ But upon the death of an ancestor the heir or devisee becomes at once vested with the full property, subject only to liens and burdens then existing or created by statutes then in force, and to the temporary right of possession of the executor or administrator. The legislature has no power thereafter to divest it, as by an enactment ordering the sale of property of a decedent for a purpose other than one for which the sale was authorized at the time of the decedent's death. ${ }^{25}$

Thus, as the Probate Act of I85I authorized a sale of a decedent's real estate by his personal representative only when the personal estate in his hands was "insufficient to pay the allowance to the family and all debts and charges of the ad-

21 Pacific Railway Co. v. Wade (1891), 91 Cal. 449, 27 Pac. 768, 25 Am.

St. Rep. 201, 13 L. R. A. 754.

22 Spreckels v. Spreckels (1897), 116 Cal. 339, 48 Pac. 228, 58 Am. St. Rep. 170,36 L. R. A. 497.

${ }^{23}$ Brenham v. Story (1870), $39 \mathrm{Cal} .179$; In re Porter's Estate (1900), 129 Cal. 86, 61 Pac. 659, 79 Am. St. Rep. 78. Pac. 335.

24 Hannon v. Southern Pacific R. R. Co. (1909), 12 Cal. App. 350, 107

25 Brenham v. Story, supra, n. 23; In re Packer's Estate (1899), 125 Cal. 396, 58 Pac. 59, 73 Am. St. Rep. 58; In re Porter's Estate, supra, $n$. 23; In re Newlove's Estate (1904), $142 \mathrm{Cal}$ 377, 75 Pac. 1083; In re Patterson's Estate (1909), 155 Cal. 626, 102 Pac. 941, 132 Am. St. Rep. 116,26 L.R.A. (N. S.) 654, 18 Ann. Cas. 625. 
ministration,"26 a subsequent statute ${ }^{27}$ authorizing the administrator of the estate of one Charles White (who died in I853) to sell at public or private sale, subject to confirmation by the probate judge "as he may deem just and proper and for the interest of said estate," all or any of the real property of the decedent as in his judgment "will best promote the interest of those entitled to the estate," is invalid to authorize a sale for any purpose other than those specified in the Probate Act. ${ }^{28}$ The amendment, to Section 1536 of the Code of Civil Procedure, ${ }^{29}$ passed in I893, authorizing a sale of real property of a decedent for the reason, additional to those theretofore recognized, that it is for the advantage, benefit and best interests of the estate and those interested therein, cannot apply in the administration of the estate of a decedent who died before the passage of the amendment; 30 but as to estates of those who die thereafter, it is in full force and effect. ${ }^{31}$

Where one died in 1879 , leaving personal property, a note and mortgage subject to sale in the administration of his estate if "for the best interests of the estate," ${ }_{32}$ whether the sale was necessary to pay debts or not, and by subsequent proceedings in the course of administration such personal property was converted into real property by foreclosure of the mortgage security and the buying in of the mortgaged property, said property was not thereby relieved of the burden of being subject to sale if "for the best interests of the estate." Consequently when by a subsequent amendment ${ }^{33}$ its sale on that ground was authorized, said land might be sold pursuant to the power thereby conferred, without interference with any vested right. ${ }^{34}$

Community property.-Under a statute of 1850 defining the property rights of husband and wife, ${ }^{35}$ the husband was given by Section 9 "the entire management and control of the common property, with the like absolute power of disposition as

${ }^{26}$ Cal. Stats. 1851, p. 448, 467.

27 Cal. Stats. 1860, p. 148, as amended by Cal. Stats. 1861, p. 152.

28 Brenham v. Story, supra, n. 23.

29 Cal. Stats. 1893, p. 212.

30 In re Packer's Estate, supra, n. 25; In re Freud's Estate (1901), 131 Cal. 667, 63 Pac. 1080, 82 Am. St. Rep. 407; In re Newlove's Estate, supra, n. 25.

31 In re Porter's Estate, supra, n. 23.

32 Cal. Code Civ. Proc., \$ 1523.

33 Cal. Stats. 1893 , p. 212.

34 In re Bazzuro's Estate (1911), 161 Cal. 71, 118 Pac. 434.

35 Cal. Stats. 1850, p. 254. 
of his own separate estate." Section II declared: "Upon the dissolution of the community by the death of either husband or wife, one-half of the common property shall go to the survivor, and the other half to the descendants of the deceased husband or wife, subject to the payment of the debts of the deceased. If there be no descendants of the deceased husband or wife, the whole shall go to the survivor, subject to such payment." The provisions of section II were amended in I86I so that in case of the death of the wife the husband took all the community property, while in case of the death of the husband the wife took but half as before, and the other half went to certain of his heirs subject to his right of testamentary disposition. ${ }^{36}$ The details of this plan were later changed in minor particulars. ${ }^{37}$ The scheme as thus developed was carried substantially into the Civil Code. ${ }^{38}$

Under these provisions, it has been held that the wife's interest in the community property, during coverture, is not vested, but is a mere expectancy like that of an heir in the property of his ancestor; ${ }^{39}$ but upon the husband's death, vests. ${ }^{40}$ It is further said that upon the dissolution of the marriage by judicial decree making no mention of property, she becomes vested with one half of the community property as cotenant with her husband. ${ }^{41}$

On the other hand, it has been held that the husband's interest in the community property is at all times vested. ${ }^{2}$ Thus section I72 of the Civil Code, giving the husband management and control and absolute power of disposition of the community property, was amended in I89I by the addition of the following pro-

36 Cal. Stats. 1861, p. 310.

37 Cal. Stats. 1863, p. 363.

$38 \S 172$ contains a provision like that of $\S 9$ of the act of 1850 , and $\S \S 1401$ and 1402 contain provisions like those of $\S 11$ as amended in 1864 .

39 Van Maren v. Johnson (1860), 15 Cal. 308; Packard v. Arellanes (1861), 17 Cal. 525; Greiner v. Greiner (1881), 58 Cal. 115, 8 Pac. Coast. L.J. 119; People v. Swalm (1889), 80 Cal. 46, 22 Pac. 67, 13 Am. St. Rep. 96; In re Burdick's Estate (1896), 112 Cal. 387, 44 Pac. 784; In re Moffitt's Estate (1908), 153 Cal. 359, 95 Pac. 653, 1025, 20 L.R.A. (N.S.) 207.

40 Packard v. Arellanes, supra, n. 39.

41 In re Burdick's Estate, supra, n. 39.

42 Van Maren v. Johnson, supra, n. 39; Packard v. Arellanes, supra, n. 39; Greiner v. Greiner, supra, n. 39; People v. Swalm, supra, n. 39; Spreckels v. Spreckels, supra, n. 22, where it was said: "The husband's ownership of one-half of the community estate is in a sense conditional. It may terminate upon the happening of a possible event. Until then, he is, however, absolute owner as defined in the code." 
viso: "provided,however, that he cannot make a gift of such community property, or convey the same without a valuable consideration, unless the wife in writing consent thereto." 43 It was held that to apply the ainendment to community property acquired prior to its passage would be to deprive the husband of a vested right of property, and is beyond legislative power. ${ }^{44}$ The following additional proviso was added in rgor: "provided, also, that no sale, conveyance, or incumbrance of the furniture, furnishing and fittings of the home, or of the clothing and wearing apparel of the wife or minor children, which is community property, shall be made without the consent of the wife." 45 It is clear that this amendinent has no application to community property acquired before such amendment.48

Again, it has been held by four justices of the Supreme Court that the husband upon the death of the wife takes all, and (two justices dissenting) that the wife upon the death of the husband takes her share of the community property by succession and not survivorship. ${ }^{47}$

The only extended argument in the decisions in support of the foregoing views is that in Spreckels v. Spreckels, ${ }^{48}$ as follows:

"Prior to the amendments of $189 \mathrm{r}$ the code vested in the husband, with reference to the community property, all the elements of ownership, and in the wife none.

"As to all the world except the wife, there was, prior to this ainendment, no distinction between the community estate and the separate estate of the husband. If suit were brought upon a liability incurred in a business, the profits of which would be community property, and judgment recovered, execution could be levied upon the separate estate of the husband and the debt entirely satisfied therefrom. His separate estate, during the entire marriage, is liable to be taken for community debts, and of course furnishes a credit in aid of community business. If the community loses, the loss may fall upon his separate estate, but his separate estate cannot profit by the success of the community.

"The separate property of the wife is exempt from all

43 Cal. Stats. 1891, p. 425.

4 Spreckels v. Spreckels, supra, n. 22; Clavo v. Clavo (1909), 10 Cal. App. 447, 102 Pac. 556, 36 L. R. A. (N. S.) 1041.

45 Cal. Stats. 1901 , p. 598.

*6 Duncan v. Duncan (1907), 6 Cal. App. 404, 92 Pac. 310.

17 In re Burdick's Estate, supra, n. 39.

*8 Spreckels v. Spreckels, supra, n. 22. 
these liabilities, but, on the other hand, the community property is liable for debts incurred by the husband in the management of his separate estate.

"Now, all these differences point to the fact that the husband is the absolute owner of the community property.

"If the property did not belong to the husband, there would be no occasion for a law limiting his testamentary power with reference thereto."

This argument leaves out of account several important considerations. The community property is the result of the industry and frugality not only of the husband but of the wife as well. In case the husband exercises his power of absolute disposition, the proceeds, if any, belong to the community. When he engages in business enterprise, it certainly is only fair that he should be willing and required to take the same risk with respect to his own separate property that he takes with respect to property to the accumulation of which the industry and frugality of another has contributed; he certamly should not take with property to which another has so contributed, a risk he is unwilling to take with his own. In the language of the code, the husband has only, as touching the community property, "entire management and control ... . with .... absolute power of disposition:" he does not have those most important elements of ownership, exclusive use, possession and enjoyment. In fact, the words just quoted, in which his power is expressed, are appropriate to the vesting in him of a power, not an estate. That he has such a power in the community property, but that the estate therem is vested in his wife equally with himself, is the only view that is entirely consistent with section 682 of the Civil Code which provides:

"The ownership of property by several persons is either:

I. Of joint interests;

2. Of partnership interests;

3. Of interest in common;

4. Of community interest of husband and wife."

As said by two justices of the Supreme Court, concurring in a judgment, but dissenting on the point to which the statement was directed :49

"The entire provisions of the Civil Code are at variance with treating the husband as the owner of the community

49 Per Harrison and Garoutte, $\mathrm{JJ}$, concurring in judgment in re Burdick's Estate, supra, n. 39. 
property. If he were the owner he would have the absolute dominion over it, with the right to use it or dispose of it according to his pleasure; but . . . . these attributes of ownership are denied him. Section 682 of the Civil Code specifies the community interest of husband and wife as one species of property which is owned by several persons. The necessary implication therefrom is that the husband and the wife are the 'several persons' in whom is vested this ownership of the community property. This ownership is not absolute in either, but in each of them is qualified by reason of its being shared with the other."

Other intimations and statements in line with the same view may also be found in the cases.50 In this view, the relation of husband and wife with reference to the community property is like that of a general to a special partner.

But, finally, in any view of the points already discussed, so far as concerned community property accumulated while section II of the act of 1850 as originally enacted was in force, the husband had no valid constitutional objection to that clause which took from him, in certain cases, upon his wife's death, one-half of the community property; he held all such property subject to the law in force when it was accumulated. ${ }^{51}$

Corporeal property: (a) Regulating use in general.-The

50 In De Godey v. Godey (1870), 39 Cal. 157, Wallace, Sprague, Crockett and Temple, $J \mathrm{~J}$., in leading opinion, said: "It is true that the interest of the wife therein pending the marriage has been termed ' $a$ mere expectancy' .... ; but while, perhaps, no other technical desiguation would so nearly define its character, it is, at the same time, an interest so vested in her as that the husband cannot deprive her of it by his will .... nor voluntarily alienate it for the mere purpose of divesting her of her claims to it."

Other cases, also declare that a voluntary conveyance by a husband of the common property, or any portion of it, for the purpose of defeating the claims of the wife, will not be sustained. Smith v. Smith (1859), 12 Cal. 216; Peck v. Brummagim (1866), 31 Cal. 440, 89 Am. Dec. 195; Lord v. Hough (1872), 43 Cal. 581.

It has also been debated whether or not a wife during coverture can maintain an action to set aside such a fraudulent transfer of community property by the husband. In Greiner v. Greiner, supra, n. 42, Morrison, C. J., and Myrick, J., concurring in the judgment, affirmed the right of the wife so to do; Thornton and Sharpstein, J J., in the leading opinion denied her right so to do until a dissolution of the marriage. In Cummings v. Cummings (1887), 2 Cal. Unrep. Cas. 774, 14 Pac. 562, Thornton, J., writing the opinion of Dep't. 2, again denied this right; but a rehearing was granted, and in the opinion on rehearing by McKinstry, J., (1888), 75 Cal. 434, 17 Pac. 442, this question was not considered. In Duncan v. Duncan, supra, n. 46, the District Court of Appeal hazarded the opinion that it was possible that under some circumstances such an action might be maintained.

51 Packard v. Arellanes, supra, n. 39. 
legislature cannot declare the usual and ordinary use of property a nuisance, when such use infringes no one's legal rights. ${ }^{52}$ An ordinance which prohibits the use of land and appurtenances in a lawful business in an innocent manner, must be declared void as an unwarranted infringement of inalienable rights of property. ${ }^{53}$

(b) Use as between adjoining owners.-The fact that a certain use of one's land will obstruct the light and air of an adjoining landowner, does not render it competent for the legislature to give such adjoining landowner the right to prevent it. ${ }^{54}$

(c) Use where subject to easement of way.-Where title to a public street of a city, subject to the public easement, is in the owners of the abutting land, any such owner, subject to reasonable regulation to insure the least interruption of the public easement, has a vested right to lay a waterpipe for his own use under the street and to make the necessary excavation therein for such, or any other, legitimate purpose that does not impede the public use. ${ }^{55}$

(d) Changing joint tenancy to tenancy in common.-A statute ${ }^{66}$ passed in I855 providing: "Every interest in real estate granted or devised to two or more persons, other than executors and trustees as such, shall be a tenancy in common unless expressly declared in the grant or devise to be a joint tenancy," thereby reversing the rule theretofore prevailing, did not destroy the joint tenancy created by a deed to two grantees, made in $1853^{.57}$

(e) Creating liens by operations of law.-A statute ${ }^{58}$ authorizing the distraint of trespassing hogs in certain counties at certain seasons of the year, and creating a lien thereon for the damage done and the cost of keeping them and of enforcing the lien, is not in excess of legislative power. ${ }^{59}$

While the validity of various provisions of the Mechanics'

52 Western Granite \& Marble Co. v. Knickerbocker (1894), 103 Cal. 111, 37 Pac. 192.

${ }_{53}$ Abbey Land \& Improvement Co. v. San Mateo County (1914), 167 Cal. 434, 139 Pac. 1068.

54 Western Granite \& Marble Co. v. Knickerbocker, supra, n. 52.

55 Colegrove Water Co. v. Hollywood (1907), 151 Cal. 425, $90 \mathrm{Pac}$. 1053, 13 L. R. A. (N. S.) 904.

${ }_{6 B}$ Cal. Stats. 1855, p. 171.

57 Dewey v. Lambier (1857), 7 Cal. 347.

58 Cal. Stats. 1857 , p. 106.

59 Rood v. McCargar (1874), 49 Cal. 117. 
Lien Law has at times been questioned, the latest decisions sustain in its entirety the law as amended in $1911 .^{60}$

60 In Hicks v. Murray (1872), 43 Cal. 515, the court held not constitutionally objectionable the provision of section 1 of Cal. Stats. 1867-8, p. 589, the Mechanics' Lien Law of 1868, that every person 'having charge of any mining, or of the construction, alteration or repair, either in whole or in part, of any building or other improvement, .... shall be held to be the agent of the owner for the purposes of this act;" also the provision of section 3 that "all liens created by this act upon any building or other improvement shall be preferred to all prior liens, mortgages, or other encumbrances upon the land upon which said building or other improvement shall have been constructed, or situated when altered or repaired." In Latson v. Nelson (1883), 2 Cal. Unrep. Cas. 199, 11 Pac. Coast L. J. 589, it was declared that the inalienable rights of property would lose much of their force should the court sustain the provision of section 1183 of the Code of Civil Procedure, as amended by Cal. Stats. 1880, p. 62, that the liens therein declared in favor of mechanics, materialmen, artisans, architects and laborers, "shall not be affected by the fact that no money is due, or to become due, on any contract made by the owner with any other party." In Gibbs v. Tally (1901), 133 Cal. 373, 65 Pac. 970, 60 L.R. A. 815, it was stated that where a landowner enters into a valid contract for the improvement of his land, the most the legislature can do is to cause the contract price to be applied to the payment of the demands of those furnishing labor and materials to the contractor. The contract price cannot be exceeded. In Hampton v. Christensen (1906), $148 \mathrm{Cal} .729,84$ Pac. 200, it was said that if the provisions of section.1184 of the Code of Civil Procedure, as amended by Cal. Stats. 1887, p. 152, should be construed as denying the owner the right, before applying, in satisfaction of liens, the payment due under that section upon the completion of a building contract, to deduct therefrom the cost of remedying defects in the performance of the contract and the damages to which under the contract he is entitled for delay in the completion of the contract, it is indubitably void. In Stimson Mill Co. v. Nolan (1907), 5 Cal. App. 754, 91 Pac. 262, in which case a rehearing was denied by the Supreme Court, it was, however, declared that where a landowner causes another to create a structure on his land, it becomes a part thereof charged with the liens of the laborers and materialmen who created it, that it having by his own act become a part of his land, it is not inequitable nor destructive of his rights to say that the liens should also extend to the land necessary for the use of the structure, and tbat it is no infringement upon any existing right of property to require the owner to pay to the laborer or materialman for the work or materials bestowed in the creation of the structure which he procured, the full value thereof. Finally, in Roystone Co. v. Darling (1915), 171 Cal. 526, 154 Pac. 15, it was held that, considered as a whole, Cal. Stats. 1911 , p. 1313, relating to the liens of mechanics and others upon real property, removing the restrictions as to the time of payment of the contract price of original construction contracts first introduced by amendment by Cal. Stats. 1885, p. 143, to section 1184 of the Code of Civil Procedure, providing that the liens of others than original contractors shall be limited only by the reasonable value and contract price of labor and materials furnished by them, irrespective of the state of accounts between the owner and original contractor, unless before the commencement of work, the original contractor, together with a bond with sureties in an amount not less tban 50 per cent of the contract price of said contract, and conditioned for the payment in full of the claims of all persons performing labor upon or furnishing materials to be used in the work contracted for, be filed in the County Recorder's office, in which event the recovery on liens must be limited to the amount due from the owner to the original contractor, was valid. 
(f) Requiring notice to avoid liens.-There is no doubt of the power of the legislature to enact that part of the Mechanics' Lien Law of $1868^{B 1}$ which provided that in case of the construction, alteration or repair of any improvement upon land with the knowledge of the owner of claimant of any interest therein, his interest shall be subject to the liens created by the act, unless within three days after he obtains knowledge of the work, or intended work, he posts written notice that he will not be responsible for the same in a conspicuous place upon said land or the improvements thereon. ${ }^{82}$ With modifications in detail, section II92 of the Code of Civil Procedure ${ }^{\text {ss }}$ has been the equivalent of this provision of the statute of I868.

(g) Recording laws.-A provision of a statute of 1850 requiring conveyances of real estate theretofore made to be recorded, and making void any such conveyance when unrecorded as against any subsequent purchaser in good faith for value whose own conveyance is first recorded, ${ }^{64}$ does not impair vested rights, notwithstanding recording was not theretofore required, it being proper to require a transferee of land to take precautions for the protection of innocent third persons from his own omission. ${ }^{\text {B5 }}$

Where, by a statute of 185 I protecting the homestead from forced sale except in certain enumerated cases, no declaration of homestead was requisite, ${ }^{60}$ but by a statute of 1860 a declaration, written, acknowledged and recorded, was required in the creation of new homesteads, it was held that there was no constitutional objection to a statute ${ }^{\mathrm{ez}}$ of $\mathrm{I} 862$, also requiring such a declaration in case of homesteads arising before the act of I86o took effect, and providing that any homestead not so declared shall cease from and after June $I, 1862 .{ }^{68}$

(h) Requiring owner to prove his title.-The Act of Congress of $185^{69}$ is not open to constitutional objection ${ }^{70}$ in requiring

${ }^{61}$ Cal. Stats. $1867-8$, p. 589.

62 Fuquay v. Stickney (1871), 41 Cal. 583; Hicks v. Murray (1872), 43 Cal. 515.

${ }^{63}$ Since the amendment by Cal. Stats. 1873-4, p. 409.

${ }^{64}$ Cal. Stats. 1850 , p. 249.

os Stafford v. Lick (1857), 7 Cal. 479.

${ }^{66}$ Cal. Stats. 1851, p. 296.

67 Cal. Stats. 1862, p. 519.

68 Noble v. Hook (1864), 24 Cal. 638.

69 (March 3, 1851), 9 U. S. Stats. at L. 631.

io Estrada v. Murpliy (186i), 19 Cal. 248. 
every claimant of land in California by Spanish or Mexican grant to present to the land commissioners constituted by the act, the documentary and oral evidence on which he relies to sustain his claim, and in providing "that all lands, the claims to which have been finally rejected . . . . and all lands the claims to which shall not have been presented to said commissioners within two years after the date of this act, shall be deemed . . . . part of the public domain of the United States," as against the claimant of a grant by imperfect title, as where the grant was of a specified quantity of land to be thereafter laid off by public authority within a much larger tract.

(i) Extending protection to mere occupant of land.-The provisions of a statute ${ }^{71}$ of 1856 passed for the protection of actual settlers on land which declared that in actions to recover land wherein plaintiff claims by federal or state patent or Spanish or Mexican grant, the defendant shall, unless his possession was obtained by force or fraud or as tenant or by entry upon inclosed lands claimed under Spanish or Mexican grant or such grant had been surveyed, and the grant, plat and field notes recorded, and the boundaries marked so as to be easily and certainly known, be entitled to set off the value of improvements made by him and of his growing crops, and that plaintiff must pay defendant such value or forfeit the land to $\mathrm{him}$, are unconstitutional. ${ }^{\mathrm{72}}$ A statute of 1858 , providing that any person heretofore or hereafter ousted from the possession of any land by a writ of restitution issued against him in an action wherein the prevailing party claimed under a foreign grant, afterwards finally rejected, or finally located so as not to include such land, is entitled, in a subsequent action against such party and those succeeding him in the possession of such land, to recover the possession of such land, and from the party by whom he was ousted his costs and damages by reason of the ouster, and from those in possession since the ouster the rents and profits of the land during the time that each was in possession, ${ }^{73}$ is unconstitutional. ${ }^{74}$

(j) Authorizing entry for mining on land held by mere occu-

${ }^{71}$ Cal. Stats. 1856 , p. 56. 514.

72 Billings v. Hall (1857), 7 Cal. 1; Lathrop v. Mills (1861), 19 Cal.

73 Cal. Stats. 1858 , p. 345.

74 Rich v. Maples (1867), 33 Cal. 102, where defendant, the holder of a Mexican grant of two leagues within a larger tract, had ousted plaintiff from the possession of a part of the larger tract not included within the grant as finally segregated. 
pancy.-A statute of 1855 made it a misdemeanor for any person for mining purposes to injure, undermine, or destroy any growing crops of grain or garden vegetables, house, building, or other superstructure, or fruit trees, the property of another upon mineral lands, without first giving such other a bond with sureties, approved by the justice of the peace of the township, in an amount to be fixed as by the act provided, and conditioned for the payment of all damages sustained by the obligee from such mining. ${ }^{75}$ In so far as this attempted to authorize one who had complied with its provisions to enter upon a tract of public mineral land of the United States, enclosed and cultivated to fruit trees and garden vegetables by the person in possession it was held to be unconstitutional..$^{78}$

(k) Requiring bond to secure payment for labor and materials bestozed in improvement upon land.77

Easements-access to and egress from public ways.-The right of the owner of a city lot to the use of the adjacent street for access to and egress from his lot is a right of property incident to the lot itself, whether he has the fee or only an easement in the street. ${ }^{78}$ But in a public highway in the country no abutter has any private easement of way as distinguished from his interest

75 Cal. Stats. 1855 , p. 145.

${ }^{78}$ Gillan v. Hutchinson (1860), 16 Cal. 154.

77 In Gibbs v. Tally, supra, n. 60 , it was held that section 1203 of the Code of Civil Procedure, as enacted by Cal. Stats. 1893, p. 202, requiring the filing in the County Recorder's office with each building contract required to be filed therein, of a bond with sureties, in the amount of 25 per cent of the contract price of the building contract, made to inure to the benefit of all persons performing labor or furnishing materials in pursuance of the building contract, providing that the persons in whose favor the bond is required may sue thereon without prejudice to their rights to liens, and making the owner and contractor jointly and severally liable in damages for the loss occasioned to anyone by a failure to file the bond, in effect required the owner to give the bond, no penalty in reality being visited upon the contractor for a failure to give it, he already being liable for all labor and materials furnished, and thus placed an additional burden upon the owner, and prevented him from improving his property without assuming such burden, and therein placed an unreasonable restraint upon him in the use thereof, and thus to some extent deprived him of it, and so was invalid. But in Roystone Co. v. Darling, supra, n. 60 , it was held that the requirement of section 1183 of the Code of Civil Procedure, as amended by Cal. Stats. 1911, p. 1313, section 1, of a somewhat similar bond, in the amount of 50 per cent of the contract price of the building contract,-unlimited recovery on liens claimed, irrespective of the state of accounts between the owner and contractor being permitted where the bond was not given,-was not open to constitutional objection.

${ }^{78}$ Schaufele v. Doyle (1890), 86 Cal. 107, 24 Pac. 834; Eachus v. Los Angeles Consol. Electric Ry. Co. (1894), 103 Cal. 614, 37 Pac. 750, 
in the common public easement. There is no covenant in favor of any abutter that it shall always exist, and so the road can be closed without making him compensation inasmuch as he has no private interest in it. ${ }^{79}$

Homesteads.-The first enactment in this state concerning homesteads was a statute passed in $18510^{80}$ Applying this statute, and reversing former decisions, the Supreme Court, in the fall of 1859 , held that notwithstanding the occupation of premises as a homestead, whether common property or the separate property of the husband, all the estate remained in the husband, a joint tenancy was not created, and the wife had no estate therein. ${ }^{81}$

The amendatory act of 1860 immediately followed. ${ }^{82}$ By section I of this act, amendatory of section 2 of the act of $185 \mathrm{I}$, and in force until superceded by the codes, it was declared that husband and wife held their homestead "as joint tenants;" and by section 1265 of the Civil Code, as enacted in 1872 , it was declared they held it "in joint tenancy." By the amendment of 1873 both these phrases were omitted..$^{83}$

At all times the homestead law has also specifically set forth the devolution of the homestead upon the death of one spouse. By section Io of the act of $185 \mathrm{I}$, it was provided that upon the death of the husband, the homestead should be set apart in certain cases by the probate court for the benefit of his surviving wife, children and heirs. By section 4 of the act of 1860 , amendatory of said section Io, it was provided that upon the death of either spouse, the homestead should be set apart by such court for the benefit of the survivor, if any, and in certain cases, of the children also. This provision was again amended in 1862 to provide that upon the death of either spouse the homestead "vests absolutely in the survivor," and so remained until the codes. ${ }^{84}$

42 Am. St. Rep. 149; Bigelow v. Ballerino (1896), 111 Cal. 559, 44 Pac. 307; Coats v. Atchison, Topeka \& Santa Fe Ry. Co. (1905), 1 Cal. App. 441, 82 Pac. 640.

${ }^{79}$ Levee District No. 9 v. Farmer (1894), 101 Cal. 178, 35 Pac. 569, 23 L.R.A. 388, the court saying: "If it were otherwise no public road would be vacated so long as it could be shown that it was necessary for a single abutter, and thus the public could be required to maintain what is in fact a private way."

80 Cal. Stats. 1851, p. 296.

81 Gee v. Moore (1859), 14 Cal. 472.

82 Cal. Stats. 1860, p. 311 .

83 Code Amendments, $1873-4$, p. 181.

84 Cal. Stats. 1862, p. 519. 
On this point section 1265 of the Civil Code as enacted 1872 declared of the homestead:

"On the death of either of the spouses .... it descends to and the title at once vests in the survivor,"

and section 1474 of the Code of Civil Procedure as enacted 1872 declared:

"On the death of the husband or wife (it) vests absolutely in the survivor."

Section 1265 was amended ${ }^{85}$ in 1873 to provide:

"If the selection was made by a married person from the community property, the land, on the death of either of the spouses, vests in the survivor ....; in other cases, upon the death of the person whose property was selected as a homestead, it shall go to their heirs or devisees, subject to the power of the probate court to assign the same for a limited period to the family of the decedent."

Section 1474 was amended in $1880^{86}$ to provide:

"If the homestead . . . . was selected from the community property or from the separate property of the person selecting or joining in the selection of the same, it vests, on the death of the husband or wife, absolutely in the survivor. If the homestead was selected from the separate property of either the husband or the wife, without his or her consent, it vests, on the death of the person from whose property it was selected, in his or her heirs, subject to the power of the superior court to assign it for a limited period to the family of the decedent."

Other more recent amendments to sections 1265 and 1474 are not material to the present discussion.

It was early decided that the interest which, by the act of I860, the children of a marriage took in the family homestead upon the death of one parent, was taken by inheritance. ${ }^{87}$ During the joint lives of their parents, they had no vested interest in the homestead. ${ }^{88}$ Thus where husband and wife declared a homestead while the act of 1860 was in effect, and the husband did not die until after the act of 1862 took effect, which made no provision for the children sharing in the homestead, the latter act applied; the homestead vested absolutely in the surviving wife, and the children of the marriage took nothing in the homestead. ${ }^{89}$

85 Cal. Stats. 1873 , p. 181.

86 Cal. Stats. 1880 , p. 77.

87 Rich v. Tubbs (1871), 41 Cal. 34; Levine v. Rovegno (1886), 71 Cal. 273, 12 Pac. 161.

88 Herrold v. Reen (1881), 58 Cal. 443, 8 Pac. Coast L. J. 961.

89 Rich v. Tubbs, supra, n. 81 ; Herrold v. Reen, supra, n. 88. 
In case of husband and wife, however, the question of vested rights is more complicated, and different questions arise accordingly as the homestead was declared between April 28, 1860 and July I, I874, when husband and wife are spoken of as joint tenants in the homestead or their interest as a joint tenancy, or before or after that period.

It must be said, however, that in most of the decisions the Supreme Court gives only cursory consideration to these questions, and pays little or no attention to the changes in statutory language. Thus it is said generally in several cases that the law in force at the death of a spouse, and not that in force at the time of the declaration of homestead, controls the rights of the surviving spouse..$^{90}$ It has also been held that the homestead act as amended in 1860 was a statute of descent.91 And in two cases where a homestead was declared while the act of 1862 was in force, but a spouse did not die until after the codes took effect, it was held that they, and not the statute of 1862 , governed the devolution of the homestead. ${ }^{22}$

The only two cases wherein the questions of vested rights have been considered at length remain to be noticed. They were decided respectively in 1877 and 1909 . In both the declaration of homestead was made while the codes as enacted in 1872 were in effect. In the first both spouses joined in a declaration of homestead on separate property of the husband, and the husband died August 1875 ; in the second the wife alone declared on separate property of the husband, and he died October 1885 . In the former case it was held that her rights vested immediately upon the

90 Tyrrell v. Baldwin (1889), 78 Cal. 470, 21 Pac. 116; Gruwell v. Seybolt (1889), 82 Cal. 7, 22 Pac. 938; Estate of Fath (1901), 132 Cal. 609, 64 Pac. 995; Saddlemire v. Stockton Sav. \& Loan Soc. (1904), 144 Cal. 650, 79 Pac. 381.

91 In re Headen's Estate (1877), 52 Cal. 294; Levine v. Rovegno, supra, n. 87; Tipton v. Martin (1886), 71 Cal. 325, 12 Pac. 244. In Herrold v. Reen, supra, n. 88, the court held that where husband and wife declared a homestead on community property August 1, 1860, and the husband died April 3,1865, the application to such homestead of the law as amended in 1862 did not interfere with the rights of the wife. The court, however, put this conclusion on the following ground: "It (the act of 1862) enlarges her right without destroying it. It enlarges her right by giving her the estate absolutely, ..... and it enlarged her right to dispose of it."

92 Gagliardo v. Dumont (1880), 54 Cal. 496, 5 Pac. Coast L. J. 305, where husband declared homestead on his separate property May 30, 1867 , and his wife died Nov. 14, 1873; Gruwell v. Seybolt, supra, n. 90, where wife declared homestead on husband's separate property in 1871, and he died July 17, 1881. 
declaration of homestead, that her interest acquired thereby was not a mere expectancy, that the code provisions did not amount to a statute of descent, that her interest was not affected by the code amendments of 1874 , that it was error for the probate court (in conformity with the amendments of 1874) to assign the homestead to her for life only, and that that court (in conformity with the codes as enacted 1872 ) should have recognized her ownership of the fee. ${ }^{93}$ In the latter case this decision was directly overruled on the ground that it failed to give any effect to the phrase of section 1265 of the Civil Code as enacted 1872 that upon the death of one spouse the homestead "descends to and at once rests in the survivor," such words in the view of the court clearly indicating that the survivor takes by descent and not by virtue of the original declaration of homestead. It was accordingly held that by her declaration of homestead the wife did not secure a vested right beyond the power of subsequent legislative control. ${ }^{94}$

The propriety of the action of a district court of appeal in overruling a decision of the Supreme Court under which a rule of property had been established for 32 years may be doubted; but apart from that matter, in the light of the distinctions pointed out by these cases, it is apparent that the decisions holding the homestead law of $I 860$ a statute of descent are correct, while those so holding with reference to the law as amended in 1862 are wrong, since the law as then amended says distinctly that husband and wife hold the homestead "as joint tenants" and that upon the death of either it "vests absolutely in the survivor," and contains not a word relating to the descent of the homestead, or setting it apart to the survivor by the probate court.

Fish and game.-It is declared by the late Chief Justice Beatty in one case: "The people of the state being the owner of its wild game, it may be conceded that the state legislature could annex any condition it chose to the privilege of taking it.95 In the later case it was stated that "The legislature had the right to permit persons to kill or take game upon such terms and conditions as its wisdom might dictate, and .... the person killing game might have such property interest in it, and such only, as the legislature might confer." ${ }^{\prime 96}$ Thus that portion of section $626 \mathrm{k}$ of the Penal

93 In re Headen's Estate, supra, n. 91.

94 Hannon v. Southern Pacific R. R. Co., supra, n. 24.

95 Ex parte Knapp (1899), 127 Cal. 101, 59 Pac. 315.

Rep. 177.

96 Ex parte Kenneke (1902), 136 Cal. 527, 69 Pac. 261, 89 Am. St. 
Code $^{97}$ which provides: "Every person who buys, sells, offers or exposes for sale, barter, or trade, any quail .... is guilty of a misdemeanor," does not violate any right of property. ${ }^{98}$ Similarly, the claim that fish caught lawfully prior to the closed season become articles of merchandise and the property of the person taking them, and that the legislature does not have power to prohibit the sale of such merchandise, and cannot restrict the right to possess the same, cannot be sustained.99

Waters.-The legislature had no power by the enactment of the codes to take away from landowners water rights acquired by them prior to the codes. ${ }^{1}$ A stream not being a public way if non-navigable, the mere legislative declaration that a certain nonnavigable stream is navigable, cannot make it a public way. ${ }^{2}$ The taking of a strip of land for highway purposes, does not authorize the public authorities to intercept and divert, without compensation to lower riparian owners, the waters of a small stream that formerly trickled across and through such strip of land. ${ }^{3}$ The water rights of the city of Los Angeles in certain streams, as against riparian owners, are those only that were possessed by the pueblo of Los Angeles before the American occupation, and can not be increased by legislative grant.* The amendment to section I4IO of the Civil Code, ${ }^{5}$ declaring all water and the use of water public property, can not affect or impair water rights which had passed into private ownership before its enactment. ${ }^{\circ}$

(TO BE CONTINUED)

Charles M. Bufford,

San Francisco, California.

${ }^{97}$ Enacted by Cal. Stats. 1901, p. 820 .

98 Ex parte Kenneke, supra, n. 96.

99 People v. Haagen (1903), 139 Cal. 115, 72 Pac. 836.

1 Lux v. Haggin (1886), 69 Cal. 255, 375, 10 Pac. 674.

2 People v. Elk River Mill \& Lumber Co. (1895), $107 \mathrm{Cal} .221,40$ Pac. 531, 48 Am. St. Rep. 125.

3 People v. Elk River Mill \& Lumber Co., supra, n. 2.

1 Los Angeles v. Pomeroy (1899), 124 Cal. 597, 57 Pac. 585.

5 Cal. Stats. 1911, p. 821.

6 Palmer v. Railroad Commission (1914), 167 Cal. 163, 138 Pac 997. 